\title{
Kebiasaan Sarapan, Kualitas Tidur, Dan Dukungan Orangtua Terhadap Konsentrasi Belajar Selama Pandemi COVID 19
}

\author{
Sukmawati* $^{*}{ }^{1}$ Harna $^{1}$, Rachmanida Nuzrina ${ }^{1}$, Laras Sitoayu $^{1}$, Lintang Purwara Dewanti ${ }^{1}$ \\ ${ }^{1}$ Program Studi Gizi, Fakultas Ilmu-Ilmu Kesehatan, Universitas Esa Unggul, Indonesia
}

Author's Email Correspondence (*): Harna@ esaunggul.ac.id

\begin{abstract}
Abstrak
Masalah yang sering ditemukan pada anak usia sekolah dasar yaitu masalah konsentrasi penyebab anak sulit berkonsentrasi saat belajar adalah karena tidak tertarik dan tidak suka dengan materi yang dipelajari serta metode yang digunakan. Konsentrasi siswa pada usia sekolah dasar menjadi lebih selektif, beradaptasi, dan terencana. Adapun faktor-faktor yang mempengaruhi konsentrasi belajar ada dua yakni faktor internal dan faktor eksternal. Faktor internal meliputi pskiologis dan fisiologis sedangkan faktor eksternal meliputi keadaan sosial dan non sosial yang termasuk kedalam faktor internal diantaranya kebiasaan sarapan, kualitas tidur, dan dukungan orangtua. penelitian ini merupakan gabungan dari 3 faktor dominan yang berpengaruh secara langsung yaitu kebiasaan sarapan, kualitas tidur, dan dukungan orangtua. Untuk melihat mana yang paling berhubungan dengan konsentrasi belajar. Untuk mengetahui hubungan kebiasaan sarapan, kualitas tidur, dan dukungan orang tua terhadap konsentrasi belajar di SDN Karawaci 13 Kota Tangerang. Menggunakan desain penelitian cross sectional dengan pendekatan observasi (pengamatan) dan wawancara. Adapun yang di observasi adalah kebiasaan sarapan, kualitas tidur, dukungan orang tua, serta konsentrasi belajar anak SDN Karawaci 13 Kota Tangerang. Sampel penelitian ini yaitu 68 Anak Usia Sekolah Dasar yang terdiri dari kelas 4 dan 5 SD. Uji statistik menggunakan uji chi- square. Dari penelitian ini karakteristik responden Menunjukkan bahwa responden penelitian mayoritas berjenis kelamin laki-laki yaitu sebanyak 39 orang $(57,4 \%)$. Untuk frekuensi usia responden mayoritas siswa SDN Karawaci 13 Berusia 11 tahun sebanyak 34 orang (50\%). Dan distribusi berdasarkan kelas siswa mayoritas siswa kelas 5 B sebanyak 23 orang $(33,8 \%)$. Hasil uji statistik hubungan antara Kebiasaan Sarapan $(0,040)$, dan Dukungan Orangtua $(0,017)$ menunjukkan adanya hubungan yang signifikan $(p \leq 0,05)$ Terhadap Konsentrasi Belajar. Terdapat hubungan yang signifikan antara kebiasaan sarapan, dukungan orangtua terhadap konsentrasi belajar di SDN Karawaci 13 Selama Pandemi COVID 19, Tidak terdapat hubungan yang signifkan Antara kualitas tidur terhadap konsentrasi Belajar di SDN Karawaci 13 Selama Pandemi COVID 19.
\end{abstract}

Kata Kunci: Konsentrasi Belajar, Kebiasaan sarapan, Kualitas tidur, Dukungan orangtua

How to Cite:

Wati, S., Harna, H., Nuzrina, R., Sitoayu, L., \& Dewanti, L. (2021). Kebiasaan Sarapan, Kualitas Tidur, Dan Dukungan Orangtua Terhadap Konsentrasi Belajar Selama Pandemi COVID 19. Ghidza: Jurnal Gizi Dan Kesehatan, 5(1), 23-33. https://doi.org/10.22487/ghidza.v5i1.164

Published by:

Tadulako University

Address:

Soekarno Hatta KM 9. Kota Palu, Sulawesi Tengah, Indonesia.

Phone: +628525357076

Email: ghidzajurnal@gmail.com
Article history :

Received : 18102020

Received in revised form : 29012021

Accepted : 29012021

Available online 02072021 


\begin{abstract}
The problem that often occurs in elementary school age children is the problem of concentration. One of the reasons why children find it difficult to concentrate while studying is because they are not interested or do not like the material being studied and the methods used. The concentration of students at primary school age becomes more selective, adaptable, and planned. There are two factors that affect the concentration of learning, namely internal factors and external factors. Internal factors include psychology and physiology, while external factors include social and non-social conditions including internal factors, including breakfast habits, sleep quality, and parental support. This study is a combination of 3 dominant factors that directly influence breakfast habits, sleep quality, and parental support. To see which one is most related to learning concentration. To The Relationship between Breakfast Habits, Sleep Quality, and Parental Support on Learning Concentration at SDN Karawaci 13 During the COVID 19 Pandemic. This study used a cross sectional study design with an approach (observation) and interviews. The sample of this research is 68 elementary school aged children. Statistical test using chi-square test. From this study, the results of the characteristics showed that the majority of respondents were male, namely as many as 39 people $(57.4 \%)$. For the age frequency of the respondents, the majority of SDN Karawaci 13 students aged 11 years were 34 people (50\%). And the distribution based on the student class, the majority of students in grade $5 \mathrm{~B}$ were 23 people (33.8\%). The statistical test results of the relationship between breakfast habits (0.040) and parental support (0.017) showed a significant relationship $(\mathrm{p} \leq 0.05)$ on learning concentration. There is a significant relationship between breakfast habits, parental support for learning concentration at SDN Karawaci 13 During the COVID 19 Pandemic, there is no significant relationship between sleep quality and learning concentration at SDN Karawaci 13 During the COVID 19 Pandemic.
\end{abstract}

Keywords: Study Concentration, Breakfast Habits, Sleep Quality, and Parental Support

\title{
I. PENDAHULUAN
}

Penutupan sementara lembaga pendidikan sebagai upaya menahan penyebaran pandemi COVID 19 diseluruh berbagai negara salah satunya Indonesia berdampak pada jutaan pelajar,tidak kecuali diIndonesia. Gangguan dalam proses belajar langsung antara siswa dan guru serta pembatalan penilaian belajar berdampak pada menurunnya kualitas keterampilan murid (Aji, 2020). Sementara itu, masalah yang sering ditemukan pada anak usia sekolah dasar yaitu masalah konsentrasi penyebab anak sulit berkonsentrasi saat belajar adalah karena tidak tertarik dan tidak suka dengan materi yang dipelajari serta metode yang digunakan (Gunawan, 2015). Masalah konsentrasi juga disebabkan oleh kurangnya minat siswa terhadap mata pelajaran yang dipelajari, serta gangguan lingkungan seperti (bising, keadaan yang semrawut, dan cuaca buruk) (Muhith, 2015). Konsentrasi siswa pada usia sekolah dasar menjadi lebih selektif, adaptif, dan terencana (Berk, 2012). Pendidikan berkualitas tinggi disekolah dasar sangat menentukan perkembangan kognitif serta konsentrasi anak (Berk, 2012).

Adapun faktor-faktor yang mempengaruhi konsentrasi belajar terdapat dua faktor yang meliputi faktor internal dan eksternal. Faktor internal terdiri dari psikologis dan fisiologis sedangkan faktor eksternal terdiri dari keadaan sosial dan non sosial. Yang termasuk kedalam faktor internal diantaranya kebiasaan sarapan, kualitas tidur dan dukungan orang tua (Almatsier et al., 2011).

Masa usia Sekolah Dasar terdiri atas siswa kelas rendah (Kelas 1, 2, dan 3 ) dan siswa kelas tinggi (Kelas 4, 5, dan 6 ). Masa ini ditandai anak mulai memasuki bangku sekolah dasar, dan dimulai sejarah baru yaitu masa pengenalan lingkungan sosial yang lebih luas (Sudarmawan, 2013). Energi yang 
dibutuhkan lebih besar karena anak lebih banyak melakukan aktifitas fisik, misalnya olahraga, bermain, atau membantu orang tua (Istiany, 2013).

Hasil penelitian Ferawati (2016) yang menyatakan bahwa ada hubunga yang signifikan antara kebiasaan sarapan dengan konsentrasi belajar (Ferawati \& Sundari, 2017). Hal ini sejalan dengan penelitian Ira Saputri (2014) yang menyatakan bahwa ada hubungan yang signifikan antara kebisaan sarapan dengan konsentrasi belajar (Saputri, 2014).

Selain itu konsentrasi belajar bisa menurun disebabkan oleh kualitas tidur yang tidak efektif. Tidur adalah salah satu dari bagian fisiologis, waktu tidur yang singkat pada anak sekolah akan mempengaruhi suasana hati dan mengurangi kinerja di sekolah (Potter \& Perry, 2015). Hal ini sejalan dengan penelitian Retnaningsih (2018) yang menunjukkan ada hubungan yang signifikan antara kulitas tidur dengan konsentrasi belajar (Retnaningsih \& Kustriyani, 2018). Kebutuhan tidur setiap umur berbeda, seiring dengan bertambahnya usia durasi tidur juga akan mengalami perubahan (Irawan et al., 2020).

Faktor lain yang dapat menyebabkan konsentrasi belajar diantaranya yaitu dukungan orang tua. Hasil penelitian Afriansyah (2014) yang menyatakan terdapat hubungan antara dukungan orangtua dengan hasil pembelajaran IPS di kelas VI SD Negeri 68 Kota Bengkulu (Afriansyah et al., 2014). Dukungan orang tua merupakan sistem dukungan sosial yang terpenting dimasa anak usia sekolah dibandingkan dengan sistem dukungan sosial lainnya. Dukungan orang tua berhubungan dengan kesuksesan akademis anak, gambaran diri yang positif, percaya diri, motivasi dan kesehatan mental (Julaiha, 2011). Tujuan dari penelitian ini untuk mengetahui hubungan antara kebiasaan sarapan, kualitas tidur, dan dukungan orang tua terhadap konsentrasi belajar di SDN Karawaci 13 Kota Tangerang.

\section{METODE}

Penelitian ini menggunakan desain penelitian cross sectional dengan pendekatan observasi (pengamatan) dan wawancara dengan menggunakan lembar observasi. Sampel penelitian ini yaitu 68 Anak Usia Sekolah Dasar didapatkan dari perhitungan sampel. 68 anak usia sekolah dasar ini hanya kelas 4 dan 5 yang diambil sampelnya. Uji statistik menggunakan uji chi- square. Tehnik pengambilan sampel menggunakan Cluster random sampling. Dengan cara melakukan randomisasi terhadap kelompok atau kelas dengan melihat jumlah sampel yaitu 68 anak maka didapatkan hasil random yaitu kelas 4 dan 5 SD. Teknik pengumpulan data dalam penelitian ini dilakukan dengan empat tahap, yaitu: pengisian kuesioner data diri, Pengisian kuesioner untuk melihat kebiasaan sarapan yang sudah dilakukan uji validitas terdapat 4 pertanyaan, Kuesioner PSQI yang sudah standar nasional terdapat 17 pertanyaan, untuk melihat kualitas tidurnya, pengisian kuesioner dukungan orang tua, yang sudah dilakukan uji validitas terdapat 10 pertanyaan. Pengisian Digit Simbol Test untuk melihat Konsentrasi Belajar. Keterbaruan dalam penelitian ini adalah lebih mengarah pada konsentras belajar siswa di SDN Karawaci 13 selama pandemi COVID 19 dan penelitian ini merupakan gabungan dari 3 faktor dominan yang mempengaruhi secara langsung yaitu kebiasaan sarapan, kualitas tidur, dan dukungan orangtua. Untuk melihat mana yang paling berhubungan 
terhadap konsentrasi belajar. Penelitian ini telah lulus kaji etik dari Komisi Etik Penelitian Universitas Esa Unggul dengan nomor 0335-20.329/DPKE-/KEP/FINAL-EA/UEU/IX/2020.

\section{HASIL}

\section{Gambaran Karakteristik Responden}

Karakteristik responden yang akan dilihat distribusinya tanpa dianalisis Lebih lanjut yaitu gambaran usia, jenis kelamin, dan kelas. Hasil distribusi responden berdasarkan usia,jenis kelamin, dan kelas disajikan dalam tabel berikut.

Tabel 1. Distribusi Frekuensi Berdasarkan Karakteristik Responden

\begin{tabular}{cl}
\hline Karakteristik & $\begin{array}{c}\text { Jumlah Sampel } \\
\mathbf{n}=\mathbf{6 8}(\boldsymbol{\%})\end{array}$ \\
\hline Jenis Kelamin & $39(57,4)$ \\
Laki-Laki & $29(42,6)$ \\
Perempuan & \\
Usia Siswa & $3(4,4)$ \\
9 Tahun & $30(44,1)$ \\
10 Tahun & $34(50,0)$ \\
11 Tahun & $1(1,5)$ \\
12 Tahun & \\
Kelas Siswa & $11(16,2)$ \\
4 A SD & $19(27,9)$ \\
4 B SD & $15(22,1)$ \\
5 A SD & $23(33,8)$ \\
5 B SD &
\end{tabular}

Pada Tabel 1 Menunjukkan bahwa responden penelitian mayoritas berjenis kelamin laki-laki yaitu sebanyak 39 orang $(57,4 \%)$. Untuk frekuensi usia responden mayoritas siswa SDN Karawaci 13 Berusia 11 tahun sebanyak 34 orang (50\%). Dan distribusi berdasarkan kelas siswa mayoritas siswa kelas 5 B sebanyak 23 orang $(33,8 \%)$. Pada variabel kebiasaan sarapan menunjukkan bahwa responden penelitian mayoritas jarang sarapan sebanyak 41 orang $(60,3 \%)$. Selalu sarapan sebanyak 27 orang (39,7\%). Siswa/I di SDN Karawaci 13 memiliki kebiasaan jarang sarapan. Berdasarkan hasil wawancara langsung oleh resopnden 10 dari 68 anak yang mengakibatkan siswa-siswi sering melewati sarapan dikarenakan tidak merasa lapar dan tidak tersedianya makanan dirumah karena orangtuanya tidak memasak dan pagi-pagi harus sudah berangkat kerja.

\section{Analisis Bivariat}

Dalam penelitian ini menggunakan uji Chi-Square yang bertujuan untuk mengetahui apakah ada hubungan atau tidak antara kebiasaan sarapan, kualitas tidur, dan dukungan orangtua terhadap konsentrasi belajar di SDN Karawaci 13 selama pandemi COVID 19. 
Tabel 2. Hubungan kebiasaan sarapan, kualitas tidur, dukungan orangtua dengan konsentrasi belajar

\begin{tabular}{lcccc}
\hline \multicolumn{1}{c}{ Variabel } & $\begin{array}{c}\text { Konsentrasi Belajar } \\
\text { kurang baik } \\
(\%)\end{array}$ & $\begin{array}{c}\text { Konsentrasi } \\
\text { Belajar Baik } \\
(\%)\end{array}$ & $\begin{array}{c}\text { Total } \\
(\%)\end{array}$ & $p$-value \\
$\begin{array}{l}\text { Kebiasaan Sarapan } \\
\text { Jarang } \\
\text { Selalu }\end{array}$ & $15(36,6)$ & $26(63,4)$ & $41(100 \%)$ & 0,040 \\
Kualitas Tidur & $3(11,1)$ & $24(88,9 \%)$ & $27(100 \%)$ & 0,177 \\
$\quad \begin{array}{l}\text { Buruk } \\
\text { Baik }\end{array}$ & $5(16,7 \%)$ & $25(83,3 \%)$ & $30(100 \%)$ & $38(100 \%)$ \\
$\begin{array}{l}\text { Dukungan Orangtua } \\
\text { Kurang }\end{array}$ & $13(34,2 \%)$ & $25(65,8 \%)$ & $15(100 \%)$ & 0,017 \\
Baik & $8(53,3 \%)$ & $7(46,7 \%)$ & $53(100 \%)$ & \\
\hline
\end{tabular}

Pada tabel 2 variabel kualitas tidur menujukkan bahwa kualitas tidur siwa-siswi mayoritas baik yaitu sebanyak 38 orang $(55,9 \%)$ dan yang buruk sebanyak 30 orang $(44,1 \%)$. Namun di SDN Karawaci 13 masih ada beberapa siswa/I ini memiliki kualitas tidur yang buruk. Berdasarkan hasil wawancara langsung oleh responden dikarenakan siswa/I tersebut sudah terbiasa tidur larut malam dan sering terbangun dimalam hari karena kepanasan serta sering mengantuk ketika melakukan aktivitas dipagi maupun disiang hari.

Pada tabel 2 variabel dukungan orangtua menunjukkan bahwa dukungan orang tua siswa mayoritas baik yaitu sebanyak 53 orang (77,9\%). Dan kurang sebanyak 15 orang $(22,1 \%)$. Namun ada beberapa siswa-siswi ini kurang mendapatkan dukungan orangtua dalam hal dukungan emosional berupa ungkapan empati dan perhatian terhadap siswa/I seperti kurang menciptakan suasana belajar anak dan kurang memberikan motivasi pada anak. Selain itu, ada juga dukungan instrumental berupa kebutuhan langsung yang dibutuhkan anak. Dukungan ini mencakup seperti penyediaan fasilitas belajar, penyediaan alat kelengkapan belajar contohnya jarang membelikan buku-buku penunjang bagi siswa/I tersebut. Pada variabel konsentrasi belajar menunjukkan bahwa konsentrasi belajar siswa mayoritas baik yaitu sebanyak 50 orang $(73,5 \%)$ dan kurang baik sebanyak 18 orang $(26,5 \%)$.

\section{PEMBAHASAN}

\section{Kebiasaan Sarapan}

kebiasaan sarapan didapatkan dari kuesioner kebiasaan sarapan dilihat pada variabel kebiasaan sarapan bahwa siswa-siswi yang tidak konsentrasi belajar yang sarapan nya jarang yaitu sebesar 36,6\% (15 responden) sedangkan yang selalu sarapan sebesar $11,1 \%$ (3 responden). Dan siswa-siswi yang konsentrasi belajarnya baik dan jarang sarapan yaitu sebesar 63,45 (26 responden) dan selalu sarapan sebesar 88,9\% (24 responden). Namun ada beberapa Siswa/I di SDN Karawaci 13 memiliki kebiasaan jarang sarapan. didapatkan hasil wawancara langsung oleh resoponden yang mengakibatkan siswa-siswi sering melewati sarapan dikarenakan tidak merasa lapar dan tidak tersedianya makanan dirumah karena orangtuanya tidak memasak dan pagi-pagi harus sudah berangkat kerja. Hasil ini sejalan dengan peneliti 
Devi (2012) mengungkapkan bahwa banyak orangtua yang bekerja sehingga tidak memiliki waktu untuk menyiapkan sarapan buat anaknya kesekolah, sehingga banyak anak sekolah tidak terbiasa sarapan (Devi, 2012).

Sarapan adalah makanan yang disantap pada pagi hari, waktu sarapan dimulai pada pukul 06.00 sampai dengan pukul 09.00 pagi. Pada dasarnya sarapan sangat penting dilakukan karena sarapan pagi merupakan sumber glukosa yang baik. Glukosa merupakan sumber energi utama kerja otak. Glukosa ini akan dibawa oleh darah keseluruh bagian tubuh yang memerlukan salah satunya otak.

Hasil uji statistik pada variabel kebiasaan sarapan diperoleh nilai p 0,040 ( $p$-value $\leq 0,05)$ maka Ho ditolak. Sehingga dapat disimpulkan bahwa ada hubungan yang signifikan antara kebiasaan sarapan dengan konsentrasi belajar. Selain itu, diperoleh juga nilai OR (Odds Ratio) pada variabel kebiasaan sarapan yaitu 4,615 yang memiliki arti siswa/I yang jarang sarapan beresiko 4,6 kali memiliki konsentrasi belajar kurang baik.

\section{Kualitas Tidur}

Selain kebiasaan sarapan, terdapat juga variabel kualitas tidur. Kualitas tidur didapatkan menggunakan kuesioner PSQI. Dilihat pada variabel kualitas tidur bahwa siswa siswi yang tidak konsentrasi belajar yang kualitas tidurnya buruk yaitu sebesar 16,7\% (5 responden) sedangkan yang kualitas tidurnya baik yaitu sebesar 34,2\% (13 responden). Dan siswa-siswi yang konsentrasi belajarnya baik dan kualitas tidurnya buruk yaitu sebesar 83,3\% (25 responden) sedangkan yang kualitas tidurnya baik sebesar 65,8\% (25 responden). Hasil uji statistik pada variabel kebiasaan sarapan diperoleh nilai $\mathrm{p}$ 0,177 ( $p$-value $\geq 0,05$ ). Sehingga dapat disimpulkan bahwa tidak ada hubungan yang signifikan antara kualitas tidur dengan konsentrasi belajar di SDN Karawaci 13. Namun di SDN Karawaci 13 masih ada beberapa siswa/I ini memiliki kualitas tidur yang buruk. didapatkan hasil wawancara langsung oleh responden dikarenakan siswa/I tersebut sudah terbiasa tidur larut malam dan sering terbangun dimalam hari karena kepanasan serta sering mengantuk ketika melakukan aktivitas dipagi maupun disiang hari

\section{Hubungan Kebiasaan Sarapan Terhadap Konsentrasi Belajar}

Hasil uji statistik menggunakan uji chi-square dapat disimpulkan bahwa ada hubungan yang signifikan antara kebiasaan sarapan $\mathrm{p}$-Value $0,040(\mathrm{p} \leq 0,05)$ terhadap konsentrasi belajar siswa-siswi SDN Karawaci 13. Dari hasil penelitian ini anak yang memiliki konsentrasi belajar baik dan selalu sarapan sebesar $88,9 \%$. Sehingga terdapat hubungan yang signifikan. Kebiasaan sarapan yang berhubungan dengan konsentrasi belajar yaitu kebiasaan sarapan yang mencakup sarapan sehat seperti makanan yang mengandung gizi seimbang, aman dikonsumsi dan tidak tergesa-gesa saat sarapan (Hardinsyah, 2013).

Kebiasaan sarapan didapatkan dari hasil ukur menggunakan kuesioner kebiasaan sarapan. Sebagian besar responden memiliki kebiasaan sarapan yang jarang sarapan 60,3\%. Hasil penelitian ini sejalan dengan hasil penelitian oleh Ferawati (2016) yang menyatakan terdapat hubungan yang bermakna antara kebiasaan sarapan dengan konsentrasi belajar (Ferawati \& Sundari, 2017). Hasil ini juga sejalan 
dengan penelitian Ira Saputri (2014) yang menyatakan bahwa terdapat hubungan yang bermakna antara kebiasaan sarapan pagi terhadap konsentrasi belajar (Saputri, 2014).

Kebiasaan sarapan pada anak akan mempengaruhi tingkat konsentrasi dalam mengikuti proses pembelajaran. Karena makan atau sarapan merupakan menu makanan yang pertama yang dikonsumsi individu. Biasanya seseorang makan malam sekitar pukul 19.00 WIB dan baru makan lagi paginya sekitar pukul 06.00 WIB. Berarti selama sekitar 10-12 jam seseorang puasa. Dengan adanya puasa, cadangan gula darah (glukosa) dalam tubuh seseorang hanya cukup untuk aktifitas 2-3 jam di pagi hari. Tanpa sarapan individu akan mengalami hipoglikemia atau kadar glukosa dibawah normal. Hipoglikemia menyebabkan tubuh gemeteran, pusing dan sulit berkonsentrasi. Itu semua karena kekurangan glukosa yang merupakan sumber energi bagi otak (Annisa \& Tanziha, 2014).

Salah satu faktor yang dapat mempengaruhi konsentrasi belajar anak adalah kondisi jasmani (Suwardhani et al., 2013). Dimana kondisi jasmani yang baik akan memberikan kemampuan tubuh untuk memusatkan perhatian. Sedangkan menurut Hakim (2016) salah satu faktor yang dapat mempengaruhi konsentrasi belajar adalah kecukupan zat gizi, dimana penelitian ini menyatakan bahwa pada dasarnya keterampilan berkonsentrasi pada anak seperti orang dewasa, konsentrasi bergantung pada suatu pemikiran. Asupan zat gizi tidak seimbang juga berpotensial menganggu konsentrasi, karena kecukupan zat gizi seimbang merupakan kebutuhan dasar untuk beraktivitas termasuk dalam memusatkan perhatian untuk mencapai konsentrasi belajar yang baik (Hakim et al., 2016).

Berdasarkan penelitian ini kebiasaan sarapan berhubungan signifikan dengan konsentrasi belajar pada anak, dimana terlihat adanya kecenderungan anak yang sarapan untuk lebih mempunyai tingkat konsentrasi yang baik jika dibandingkan dengan anak yang tidak sarapan. Sarapan sangat penting untuk dilakukan, karena sebelum sarapan tubuh telah berpuasa selama antara 9-12 jam kondisi ini menyebabkan tubuh kekurangan karbohidrat (glukosa), jika seorang anak tidak memiliki kebiasaan sarapan sebelum beraktivitas atau belajar, maka akan rentan terhadap hipoglikemia yang mengakibatkan tubuh gemeteran, pusing dan sulit berkonsentrasi akibat kekurangan glukosa yang merupakan sumber energi bagi otak, sehingga kebiasaan sarapan akan berpengaruh terhadap tingkat konsentrasi belajar pada anak.

\section{Hubungan Kualitas Tidur Terhadap Konsentrasi Belajar}

Berdasarkan penelitian ini didapatkan bahwa sebagian besar kualitas tidur responden baik sebesar $55,9 \%$ dengan skor $\leq 5$. Dan didapatkan hasil p-Value 0,177 ( $\operatorname{sig} \geq 0,05$ ), sehingga H0 gagal ditolak yang berarti tidak ada hubungan antara kualitas tidur terhadap konsentrasi belajar siswa-siswi di SDN Karawaci 13. Hal ini bertentangan dengan penelitan Retnaningsih (2018) yang menyatakan bahwa ada hubungan yang signifikan antara kualitas tidur dengan konsentrasi belajar pada anak usia sekolah di SDN 3 Candisari Kecamatan Purwodadi Kabupaten Grobogan (Retnaningsih \& Kustriyani, 2018). Hasil ini juga bertentangan dengan hasil penelitian oleh Astari Savitri (2019) yang menyatakan bahwa tidak terdapat hubungan yang bermakna antara kualitas tidur dengan konsentrasi belajar mahasiswa ilmu keperawatan di UPN Veteran Jakarta (Savitri, 2019). 
Kualitas tidur yang buruk dapat menyebabkan kurangnya tingkat kewaspadaan yang berakibat pada penurunan konsentrasi. Oleh karena itu sering menimbulkan manifestasi klinis seperti mengantuk yang dapat menyebabkan tidak mampu berkonsentrasi dan berpikir dengan jelas. Kemampuan konsentrasi dipengaruhi neurotransmitter serotonin. Pada saat seseorang kurang tidur, jumlah neurotransmitter serotonin juga berkurang sehingga untuk memperoleh serotonin yang adekuat, diperlukan kualitas tidur yang baik (Robotham et al., 2011).

Syamsoedin (2015) mengatakan bahwa kebiasaan sebelum tidur yang dilakukan seseorang juga mempengaruhi kualitas tidurnya. Kebiasaan tidur larut malam tidak hanya karena ada tugas atau pekerjaan rumah, tetapi juga adanya faktor elektronik seperti bermain handphone, mengakses internet, mendengarkan musik, dan menonton televisi. Tidak adanya korelasi antara kualitas tidur dengan kemampuan konsentrasi belajar disebabkan karena adanya faktor lain yang menyebabkan penurunan kemampuan konsentrasi belajar, tidak hanya faktor kualitas tidur saja. Seseorang yang memiliki kualitas tidur baik namun konsentrasi belajarnya menurun dapat disebabkan oleh faktor lain seperti adanya masalah internal, siswa tidak minat belajar, modalitas belajar yang kurang, faktor lingkungan, dan pergaulan. Selain itu, siswa/i yang terbiasa tidur larut malam dan memiliki kualitas tidur yang buruk tetapi dapat mempertahankan konsentrasi belajarnya menandakan siswa/i tersebut sudah beradaptasi. Kualitas tidur buruk sebaiknya disikapi dengan melakukan perubahan pola tidur pada masing-masing individu (Syamsoedin et al., 2015). Hal ini sejalan dengan penelitian Andriani (2016) tentang faktorfaktor yang mempengaruhi kualitas tidur salah satunya yaitu keterlambatan waktu tidur (Andriani, 2016).

Berdasarkan penelitian ini kualitas tidur tidak berhubungan dengan konsentrasi belajar anak di SDN Karawaci 13. Dimana terlihat adanya kecenderungan anak yang kualitas tidurnya buruk namun memiliki konsentrasi belajar yang baik yaitu sebesar 83,3\% sedangkan kualitas tidur buruk namun konsentrasi belajarnya kurang baik 16,7\%. Terdapat 21 responden yang diwawancarai menyatakan sering terlambat tidur dikarenakan karena semenjak adanya COVID 19 merasa bahwa tidak harus bangun lebih awal karena tidak berangkat kesekolah. Aktivitas yang membuat anak sekolah dasar ini terlambat tidur dikarenakan bermain handphone. Siswa/I ini juga sering mengantuk ketika melakukan aktivitas dipagi maupun siang hari yang membuatnya lemas dan tidak bugar sehingga membuat kualitas tidurnya buruk.

\section{Hubungan Dukungan Orangtua Terhadap Konsentrasi Belajar}

Hasil penelitian ini didapatkan bahwa dukungan orangtua dengan p-Value 0,017 (sig $\geq 0,05$ ), yang artinya ada hubungan yang signifikan antara dukungan orangtua terhadap konsentrasi belajar siswa/i di SDN Karawaci 13. Dari hasil penelitian ini anak yang dukungan orangtuanya baik dan memiliki konsentrasi belajar baik sebanyak 43 responden $(81,1 \%)$. Dukungan orangtua yang berhubungan dengan konsentrasi belajar seperti halnya memberikan motivasi kepada anak, menciptakan suasana belajar anak, mendorong anak untuk semangat belajar, menasehati anak serta menyediakan fasilitas belajar.

Responden penelitian sebagian besar memiliki dukungan orangtua yang baik 77,9\% Penelitian ini sejalan dengan penelitian Afriansyah (2013) yang menyatakan terdapat hubungan antara dukungan 
orangtua dengan hasil pembelajaran IPS di kelas VI SD Negeri 68 Kota Bengkulu (Afriansyah et al., 2014).

Hubungan dukungan orangtua terhadap konsentrasi belajar sangat penting dalam hal pandemi seperti ini. Dukungan orangtua yang penuh akan menambah motivasi belajar anak. Dengan motivasi belajar yang baik, maka konsentrasi belajar akan baik pula(Legault et al., 2006).

Faktor keluarga menjadi salah satu faktor pemicu proses belajar anak. Dalam keluarga terdapat orang tua sebagai guru pertama dalam kehidupan anak. Perhatian dibutuhkan untuk menunjang proses belajar anak di rumah. Pada hakikatnya perhatian adalah pemusatan/kekuatan jiwa tertuju pada suatu objek (Soemanto, 2012). Perhatian orang tua adalah pemusatan/kekuatan terhadap tingkah laku serta aktifitas siswa secara sadar yang ditujukan untuk anak.

Berdasarkan hasil observasi dari peneliti. Dukungan orangtua berpengaruh terhadap konsentrasi belajar anak, karena anak cenderung berpeluang ingin mendapatkan dukungan orangtua yang baik. Orangtua berperan penting bagi proses perkembangan anak Apalagi dalam hal pandemi seperti ini siswasiswi banyak menghabiskan waktu bersama orangtua dan keluarganya dalam hal segi proses pembelajaran dan lain-lain. Hal ini didukung oleh penelitian Rianti \& Rahardjo (2014) yang mengemukakan bahwa siswa memiliki dukungan orangtua yang baik itu akan lebih berprilaku positif dan mampu bertanggung jawab sebagai pelajar (Rianti \& Rahardjo, 2014). Selain itu juga orangtua mampu untuk memandu, mengarahkan, mengatur dan displin yang mempengaruhi konsentrasi belajar dalam menunjang prestasi anak. Keterbatasan dalam penelitian ini yang dapat dijadikan evaluasi yaitu faktorfaktor yang mempengaruhi konsentrasi belajar. Tidak semua faktor yang mempengaruhi konsentrasi belajar diteliti seperti keadaan lingkungan, modalitas belajar, kondisi jasmani dan pergaulan. Data didapatkan dalam waktu yang bersamaan.

Maka dari itu penting adanya tindakan dan arahan dari pihak sekolah maupun orangtua untuk selalu mengingatkan dan memberikan edukasi tentang pentingnya sarapan terutama pada anak usia sekolah demi meningkatkan konsentrasi belajar dan menunjang prestasi belajar anak disekolah.

\section{KESIMPULAN}

Berdasarkan hasil penelitian tentang hubungan Kebiasaan Sarapan, Kualitas Tidur dan Dukungan Orangtua terhadap Konsentrasi Belajar di SDN Karawaci 13 selama pandemi COVID 19, maka dapat disimpulkan terdapat 73,5\% siswa/i memiliki konsentrasi belajar baik. Dan 26,5\% memiliki konsentrasi belajar kurang baik, ada hubungan antara kebiasaan sarapan dan dukungan orangtua terhadap konsentrasi belajar di SDN Karawaci 13 selama Pandemi COVID 19, Tidak ada hubungan antara kualitas tidur terhadap konsentrasi belajar di SDN Karawaci 13 selama Pandemi COVID 19. Saran untuk responden agar lebih memperhatikan pemenuhan kebutuhan gizi seimbang dalam hal sarapan dan memperhatikan waktu yang baik untuk sarapan sehingga siswa tidak terganggu dalam kondisi kesehatan seperti lemas yang menyebabkan sulit konsentrasi dalam proses pembelajaran. Untuk peneliti selanjutnya dapat meneliti variabel lain yang diduga berpengaruh terhadap konsentrasi belajar seperti, kondisi jasmani, minat belajar dan faktor lingkungan. 


\section{UCAPAN TERIMA KASIH}

Manuskrip ini telah diikutkan pada Scientific Article Writing Training (SAWT) Batch III Program Kerja GRAET 4.1.e, Program Studi S1 Gizi, Fikes, Universitas Esa Unggul dengan dukungan fasilitator: Dudung Angkasa, S.Gz., M.Gizi., RD; Khairizka Citra Palupi, S.Gz., MS; Laras Sitoayu, SGz., MKM, RD beserta tim dosen prodi ilmu gizi lainnya. SAWT Batch III juga mendapatkan dukungan dana dari Universitas Esa Unggul. Peneliti juga mengucapkan terimakasih kepada ibu dosen pembimbing serta penguji yang telah membimbing, memberikan kritik dan saran, dalam menyelesaikan penelitian ini, kepada seluruh responden yang telah membantu melengkapi data dalam penelitian ini serta ibu kepala sekolah SDN Karawaci 13 yang sudah memberikan perizinan kepada peneliti untuk melakukan penelitian ini.

\section{DAFTAR PUSTAKA}

Afriansyah, D., Dadi, S., \& Hasnawati, H. (2014). Hubungan Antara Dukungan Orang Tua Dengan Hasil Belajar Siswa Pada Pembelajaran Ips Dikelas VI SD Negeri 68 Kota Bengkulu [PhD Thesis]. Universitas Bengkulu.

Aji, R. H. S. (2020). Dampak COVID-19 pada pendidikan di indonesia: Sekolah, keterampilan, dan proses pembelajaran. Salam: Jurnal Sosial Dan Budaya Syar-i.(7), 5, 395-402.

Almatsier, S., Soetardjo, S., \& Soekatri, M. (2011). Gizi Seimbang dalam Daur Kehidupan. Gramedia Pustaka Utama.

Andriani, A. (2016). Hubungan Kualitas Tidur terhadap Konsentrasi Belajar Mahasiswa Akademi Kebidanan Internasional Pekanbaru Tahun 2016. Scientia Journal, 4(4), 383-390.

Annisa, P. A., \& Tanziha, I. (2014). Densitas Energi Konsumsi, Status Gizi, Dan Daya Ingat Sesaat Anak Usia Sekolah Dasar. Jurnal Gizi Dan Pangan, 9(3), Article 3. https://doi.org/10.25182/jgp.2014.9.3.\%p

Berk, L. E. (2012). Development Through The Lifespan-Dari Prenatal Sampai Remaja. Yogyakarta: Pustaka Pelajar.

Devi, N. (2012). Gizi Anak Sekolah. Kompas. https://opac.perpusnas.go.id/DetailOpac.aspx?id=818477\# Ferawati, \& Sundari, S. (2017). Hubungan Kebiasaan Sarapan Pagi Dengan Konsentrasi Belajar SiswaSiswi SD Muhammadiyah Karang Tengah Imogiri Bantul Yogyakarta. Jurnal Ilmu Kebidanan, 4(1), 53-61.

Gunawan, A. W. (2015). Mengapa Anak Sulit Konsentrasi. http://adiwgunawan.com/?p=article\&action=shownews\&pid=257

Hakim, A., Utami, N., \& Maulida, A. (2016). Hubungan Asupan Protein Dan Status Gizi Dengan Prestasi Belajar Siswa SMP Al-Azhar Palu 2014. Preventif: Jurnal Kesehatan Masyarakat, 5(2), Article 2. http://jurnal.untad.ac.id/jurnal/index.php/Preventif/article/view/5749 
Irawan, A. M. A., Umami, Z., Yusuf, A. M., \& Harna, H. (2020). Aktivitas Fisik, Durasi Tidur dan Tingkat Kecukupan Energi pada Anak Obesitas di SD Islam Al Azhar 1. JURNAL Al-AZHAR INDONESIA SERI SAINS DAN TEKNOLOGI, 5(4), 186-190.

Istiany, A. R. (2013). Gizi Terapan. PT Remaja Rosdakarya.

Julaiha, S. (2011). Balanced Score Card (BSC) sebagai Alternatif Pengukuran Kinerja Lembaga Pendidikan. Dinamika Ilmu: Jurnal Pendidikan, 11(2).

Legault, L., Green-Demers, I., \& Pelletier, L. (2006). Why do high school students lack motivation in the classroom? Toward an understanding of academic amotivation and the role of social support. Journal of Educational Psychology, 98(3), 567-582. https://doi.org/10.1037/0022-0663.98.3.567

Muhith, A. (2015). Pendidikan keperawatan jiwa: Teori dan aplikasi. Penerbit Andi.

Potter, P. A., \& Perry, A. G. (2015). Buku Ajar Fundamental Keperawatan: Konsep, Proses, Dan Praktik (Ed. Ke-4). EGC.

Retnaningsih, D., \& Kustriyani, M. (2018). Hubungan Antara Kualitas Tidur dengan Konsentrasi Belajar pada Anak Usia Sekolah di SD Negeri 3 Candisari Kecamatan Purwodadi Kabupaten Grobogan. Jurnal Ners Widya Husada, 1(1).

Rianti, D. F., \& Rahardjo, P. (2014). Kontrol Diri Pada Peserta Didik Di SMP Negeri 2 Kutasari, Purbalingga Tahun Pelajaran 2012/2013. Psycho Idea, 12(1), Article 1. https://doi.org/10.30595/psychoidea.v12i1.518

Robotham, D., Chakkalackal, L., \& Cyhlarova, E. (2011). The impact of sleep on health and wellbeing. Mental Health Foundation.

Saputri, I. (2014). Hubungan Kebiasaan Sarapan Pagi Dengan Konsentrasi Belajar Anak Usia Sekolah Di SD Negeri 69 Kecamatan Syiah Kuala Banda Aceh. ETD Unsyiah, 1(1), Article 1. http://etd.unsyiah.ac.id/index.php?p=show_detail\&id=7964

Savitri, A. (2019). Studi Korelasi Antara Kecemasan Menghadapi Ujian Dan Kualitas Tidur Dengan Kemampuan Konsentrasi Belajar Pada Mahasiswa Program Studi Ilmu Keperawatan UPN “Veteran” Jakarta [PhD Thesis]. Universitas Pembangunan Nasional Veteran Jakarta.

Soemanto, W. (2012). Psikologi pendidikan: Landasan kerja pemimpin pendidikan. Jakarta: Rineka Cipta.

Sudarmawan. (2013). The Relationship Between Knowledge And Attitudes About The Various Snack Choice With The Food Selecting Of Children's Behavior In Sdn Sambikerep II/480 Surabaya. Jurnal Pendidikan Olahraga Dan Kesehatan, 1. https://ejournal.unesa.ac.id/index.php/jurnalpendidikan-jasmani/article/view/2811

Suwardhani, F. M., Irdawati, S. K., Suryandari, D., \& Ns, S. K. (2013). Perbedaan Tingkat Konsentrasi Pada Siswa Yang Melakukan Sarapan Pagi Dengan Yang Tidak Melakukan Sarapan Pagi Di SDN Gondang III Kecamatan Nawangan Pacitan [PhD Thesis]. Universitas Muhammadiyah Surakarta. 
Syamsoedin, W. K. P., Bidjuni, H., \& Wowiling, F. (2015). Hubungan Durasi Penggunaan Media Sosial Dengan Kejadian Insomnia Pada Remaja Di SMA Negeri 9 Manado. JURNAL KEPERAWATAN, 3(1), Article 1. https://ejournal.unsrat.ac.id/index.php/jkp/article/view/6691 